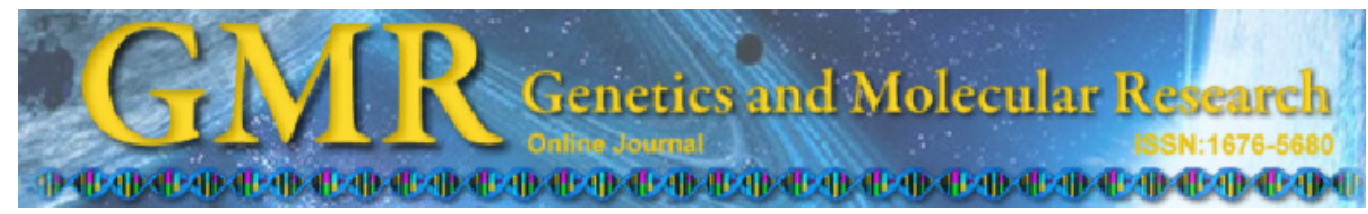

Methodology

\title{
A modified method for high-quality DNA extraction for molecular analysis in cereal plants
}

\author{
Z.H. Pervaiz ${ }^{1,2}$, N.A. Turi ${ }^{2}$, I. Khaliq ${ }^{3}$, M.A. Rabbani' ${ }^{2}$ and S.A. Malik ${ }^{1}$ \\ ${ }^{1}$ Department of Biochemistry, Quaid-e-Azam University, Islamabad, Pakistan \\ ${ }^{2}$ Plant Genetic Resources Institute, National Agricultural Research Centre, \\ Islamabad, Pakistan \\ ${ }^{3}$ School of Life Sciences, University of Sussex, Brighton, United Kingdom
}

Part of a Ph.D. thesis presented by Z.H. Pervaiz to the Department of Biochemistry, Quaid-e-Azam University, Islamabad, Pakistan.

Corresponding author: Z.H. Pervaiz

E-mail: zahidahasan82pk@hotmail.com

Genet. Mol. Res. 10 (3): 1669-1673 (2011)

Received February 24, 2011

Accepted July 26, 2011

Published August 5, 2011

DOI http://dx.doi.gov/10.4238/vol10-3gmr1346

\begin{abstract}
Cereal crops that have rigid non-cellulose components in the cell wall tissues of leaves and high starch and protein content in grains face limitations in DNA extraction. Advanced molecular genetic techniques such as mapping and marker-assisted selection programs require pure and quick DNA extraction. In this study, we developed methods for isolating high-quality genomic DNA from leaves and seeds of major cereal crops with minor modifications. DNA yields ranged from 300 to $1800 \mathrm{ng}$ for $0.01 \mathrm{~g}$ seed or leaf tissue.
\end{abstract}

Key words: DNA extraction; PCR; Cereal seeds 


\section{INTRODUCTION}

All cereals that belong to the monocot family have leaves with major sclarenchyma tissues and high seed protein and starch content. The world's top three cereals ranked on the basis of monetary value are rice, followed by wheat and corn. Pure and rapid DNA extraction is a pre-requisite step for the most advanced techniques such as genetic mapping, fingerprinting, marker-assisted selection, and nowadays for checking the authencity/adulteration of exported cereal varieties. The extraction of high-quality DNA from plant tissue is lengthy, arduous and costly because of the multiple steps (Kang et al., 1998; Paris and Carter, 2000; Kasajima et al., 2004; Xin et al., 2005; Allen et al., 2006; Bashalkhanov and Rajora, 2008). Most of the purposed methods for DNA extraction are in one way or another modified versions of hexadecyltrimethylammonium bromide (CTAB) extraction (Murray and Thompson, 1980) having some crop-to-crop limitations and varying in time and cost. The main cause of diversity and modification in CTAB protocol is the composition of cell walls and intra- and extra-cellular components. CTAB is a cationic surfactant providing a buffer solution for dissociation and selective precipitation of DNA from histone proteins (Allen et al., 2006). Monocot plant cell walls have a unique structure (Aohara et al., 2009). Lignification of cereal cell walls makes degradation difficult, which results in restricted DNA extraction. Depending upon the availability of the tissues we have standardized simple and modified methods for cereal DNA extraction from seeds as well as leaf tissues.

\section{MATERIAL AND METHODS}

Total genomic DNA was extracted from dried seeds and leaf tissues, which appear to reduce extraction costs, and time and labor used in extracting DNA from seedling samples.

\section{Reagents and solutions}

- $\quad$ Proteinase K

- RNase A

- Extraction buffer: $100 \mathrm{mM}$ Tris-HCl, pH 8.0, 20 mM EDTA, pH 8.0, 1.4 M NaCl, $2 \%$ CTAB (w/v), 1\% PVP (polyvinylpyrrolidone 40,000), Proteinase K $(50 \mu \mathrm{g} / \mathrm{mL}$ )

- For leaf tissue add $1 \%(\mathrm{v} / \mathrm{v})$ beta mercaptoethanol immediately before use to avoid possible oxidation

- Phenol:chloroform:isopropanol (25:24:1)

- $70 \%$ ethanol

- $\quad 3 \mathrm{M}$ sodium acetate solution (as chelating agent for final precipitation of pure DNA)

- TE buffer, $\mathrm{pH}$ 8.0.

\section{Procedure}

\section{For cereal seeds}

Remove seed coat and grind individual seeds from each sample with a mortar and pestle. Place $0.01 \mathrm{~g}$ sample seed powder in separate microcentrifuge tubes $(1.5 \mathrm{~mL})$. 
Add $400 \mu \mathrm{L}$ extraction buffer solution and incubate at $65^{\circ} \mathrm{C}$ for $30 \mathrm{~min}$.

\section{For cereal leaves}

Place $0.01 \mathrm{~g}$ surface sterilized finely ground leaf tissues in $500 \mu \mathrm{L}$ extraction buffer. Place $400 \mu \mathrm{L}$ leaf extract into microcentrifuge tube $(1.5 \mathrm{~mL})$.

\section{Common steps}

Add $500 \mu \mathrm{L}$ phenol:chloroform:isoamyl alcohol (25:24:1) and mix vigorously through inversion for 8-10 min. Centrifuge at $12,000 \mathrm{rpm}$ for $10 \mathrm{~min}$ at $4^{\circ} \mathrm{C}$ and transfer supernatant to new tubes.

Add $2 / 3$ volume ice-cold isopropanol and incubate tubes at room temperature for 10 min to precipitate DNA.

Centrifuge at 12,000 rpm for 5 min and remove supernatant.

Wash DNA pellet with $70 \%$ ethanol $(500 \mu \mathrm{L})$. Centrifuge at $12,000 \mathrm{rpm}$ for $5 \mathrm{~min}$ at room temperature and pour off $70 \%$ ethanol.

Remove RNA by adding $1 \mu \mathrm{L}$ RNase $(10 \mathrm{mg} / \mathrm{mL})$ and incubate at $37^{\circ} \mathrm{C}$ for $30 \mathrm{~min}$.

Add $50 \mu \mathrm{L} 3 \mathrm{M}$ sodium acetate and let sit for $10 \mathrm{~min}$.

Precipitate purified DNA by centrifugation at $12,000 \mathrm{rpm}$ with $500 \mu \mathrm{L} 70 \%$ ethanol for $10 \mathrm{~min}$ at $4^{\circ} \mathrm{C}$.

Dry pellet to completely remove ethanol residues and dissolve in $100 \mu \mathrm{L}$ TE buffer and store at $4^{\circ} \mathrm{C}$.

\section{RESULTS AND DISCUSSION}

DNA concentration and purity of each sample was determined spectrophotometrically at a wavelength of 260 and $280 \mathrm{~nm}$ using a NanoDrop ND-1000 Spectrophotometer. The ratio between absorbance at 260 and $280 \mathrm{~nm}(260 / 280)$ was used to estimate DNA purity. DNA of each sample was diluted to a working concentration of $20 \mathrm{ng} / \mu \mathrm{L}$ for polymerase chain reaction (PCR) analysis. A ratio of absorbance at 260 to $280 \mathrm{~nm}$ of 1.93 to 2.27 indicated insignificant levels of contaminating proteins and polysaccharides. Most authors use liquid nitrogen or freeze-drying for primary extraction (Cota-Sanchez et al., 2006; Allen et al., 2006) but in this method we extracted quality DNA without the use of liquid nitrogen. A number of PCR-based techniques were used to verify the DNA quality and the effect of contaminants on PCR. Simple sequence repeats (SSRs), or microsatellites, are most suited to routine application in high-throughput molecular genetic analyses, such as breeding programs and gene mapping (Pervaiz et al., 2010a). In this technique, we used both specific as well as random amplification by using microsatellite and RAPD markers. OPA-09 was used to check the quality of the DNA in three cereal crop lines (15 rice varieties, 10 wheat and 10 maize). No blank lane was observed, which confirms high-quality and the specific required quantity of DNA (Figure 1). Random amplification is highly affected by the quality and quantity of the DNA (Pervaiz et al., 2010b). Optimal DNA concentration required for a standard random amplification is 20-30 $\mathrm{ng}$ (Figure 2A-C). 


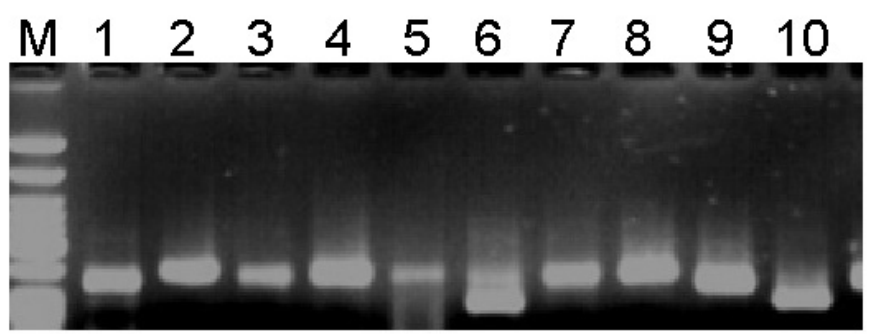

Figure 1. Microsatellite analysis of rice genotypes using RM 241. Figure shows all lanes with amplified products. Lane $M=$ molecular weight marker; lane $1=$ Basmati-370(P); lane $2=$ Mushkan; lane $3=$ Basmati-Park; lane 4 $=$ IR8; lane $5=$ Basmati-198; lane $6=$ Super-Basmati; lane $7=$ JP5; lane $8=$ Mahlar-346; lane $9=$ Shahkar; lane $10=$ Shandar.
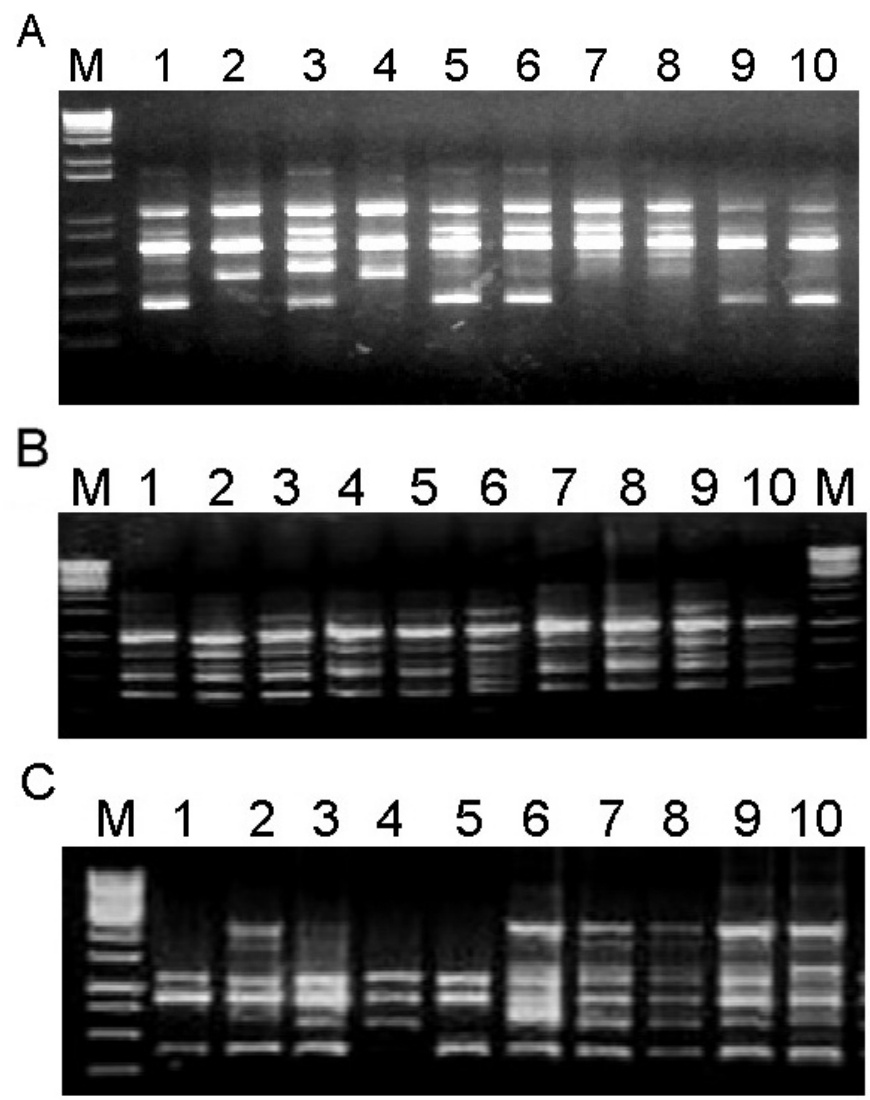

Figure 2. A. Random amplification of different varieties of rice. Lane $M=$ molecular weight marker; lane $1=$ Basmati-370(P); lane 2 = Mushkan; lane 3 = Basmati-Park; lane $4=$ IR8; lane 5 = Basmati-198; lane $6=$ SuperBasmati; lane 7 = JP5; lane $8=$ Mahlar-346; lane $9=$ Shahkar; lane $10=$ Shandar. B. Random amplification of different varieties of wheat. Lane $M=$ molecular weight marker; lane $1=$ Punjab 88; lane 2 = Pasban-90; lane 3 $=$ Kaghan-93; lane 4 = Punjnad-88; lane $5=$ Punjab-81; lane $6=\mathrm{SA}-75$; lane $7=$ Maxi-Pak; lane $8=$ Indus-79; lane $9=$ Pavon; lane $10=\mathrm{C}-228$. C. Random amplification of different varieties of maize. Lane $M=$ molecular weight marker; lane 1 = PSEV 3-2; lane $2=$ Sarhad (W); lane $3=$ Azam; lane $4=\mathrm{Jalal}$; lane $5=$ Pop. 2006; lane $6=\mathrm{WD}-3 * 6$; lane $7=$ Pop. 2004 B; lane $8=$ Gh-3*Tam1; lane $9=$ Pahari; lane $10=$ WD- $2 * 8$. DNA extracted using modified protocol. 


\section{ACKNOWLEDGMENTS}

We gratefully acknowledge the financial support from the Agricultural Linkages Program, PARC under the AREP. Financial assistance from the Higher Education Commission, Islamabad, Pakistan, is also gratefully acknowledged in form of scholarship to Z.H. Pervaiz. Authors are also very grateful to Dr. M. Shahid Masood, Senior Director General, PGRI, NARC, Islamabad, for providing laboratory facilitation for this study.

\section{REFERENCES}

Allen GC, Flores-Vergara MA, Krasynanski S, Kumar S, et al. (2006). A modified protocol for rapid DNA isolation from plant tissues using cetyltrimethylammonium bromide. Nat. Protoc. 1: 2320-2325.

Aohara T, Kotake T, Kaneko Y, Takatsuji H, et al. (2009). Rice BRITTLE CULM 5 (BRITTLE NODE) is involved in secondary cell wall formation in the sclerenchyma tissue of nodes. Plant Cell Physiol. 50: 1886-1897.

Bashalkhanov S and Rajora OP (2008). Protocol: A high-throughput DNA extraction system suitable for conifers. Plant Methods 4: 20.

Cota-Sanchez H, Remarchuk K and Ubayasenaj (2006). Ready-to-use DNA extracted with a CTAB method adapted for herbarium specimens and mucilaginous plant tissue. Plant Mol. Biol. Rep. 24: 161-167.

Kang HW, Cho YG, Yoon UH and Eun MY (1998). A rapid DNA extraction method for RFLP and PCR analysis from a single dry seed. Plant Mol. Biol. Rep. 16: 1-9.

Kasajima I, Ide Y, Ohkama-Ohtsu N, Hayashi H, et al. (2004). A protocol for rapid DNA extraction from Arabidopsis thaliana for PCR analysis. Plant Mol. Biol. Rep. 22: 49-52.

Murray MG and Thompson WF (1980). Rapid isolation of high molecular weight plant DNA. Nucleic Acids Res. 8: 43214326.

Paris M and Carter M (2000). Cereal DNA: a rapid high-throughput extraction method for marker-assisted selection. Plant Mol. Biol. Rep. 18: 357-360.

Pervaiz ZH, Rabbani MA, Khaliq I, Pearce SR, et al. (2010a). Genetic diversity associated with agronomic traits using microsatellite markers in Pakistani rice landraces. Electron. J. Biotech. 13: 1-5.

Pervaiz ZH, Rabbani MA, Shinwari ZK, Masood MS, et al. (2010b). Assessment of genetic variability in rice (Oryza sativa L.) germplasm from Pakistan using RAPD markers. Pak. J. Bot. 42: 3369-3376.

Xin X, Shinji K, Tatsuhito F and Chuntai W (2005). A protocol for high-throughput extraction of DNA from rice leaves. Plant Mol. Biol. Rep. 23: 291-295. 